\title{
Surgical consideration in a patient with cirrhosis with severe portal hypertension
}

\author{
Anna Cavazza ำ, ${ }^{1}$ Chris Willars, ${ }^{1}$ Stephen Gregory ${ }^{2}$
}

${ }^{1}$ Liver Intensive Care, King's College Hospital NHS Foundation Trust, London, UK ${ }^{2}$ Department of Radiology, King's College Hospital NHS Foundation Trust, London, UK

\section{Correspondence to Dr Anna Cavazza; a.cavazza1@gmail.com}

Accepted 7 September 2021

Check for updates

(c) BMJ Publishing Group Limited 2021. No commercial re-use. See rights and permissions. Published by BMJ.

To cite: Cavazza A, Willars C, Gregory S. BMJ Case

Rep 2021;14:e244936.

doi:10.1136/bcr-2021-

244936

\section{DESCRIPTION}

A 54-year-old man with a background of repaired large inguinoscrotal hernia, right nephrectomy for renal cell carcinoma, treated hepatitis $\mathrm{C}$ virus and alcohol-related cirrhosis. He initially presented with grade I encephalopathy (HE) and was started on rifaximin. On imaging, there was evidence of cirrhosis, portal hypertension (PHT) and splenomegaly. $\mathrm{He}$ developed portal vein thrombosis and was treated with warfarin. He had recent episodes of decompensation with non-variceal haemorrhage, scrotal cellulitis and acute kidney injury. A renal biopsy was planned in view of deteriorating renal function and proteinuria while being assessed for transplant.

He was admitted to the Intensive Care Unit (ICU) postelective left renal biopsy which was complicated by a large retroperitoneal bleed requiring renal artery embolisation. The bleeding was considered a recognised complication postbiopsy not related to PHT as no significant splenorenal varices were present. The CT scan demonstrated an epigastric hernia and a left portal vein recanalising to the paraumbilical vein. The left external iliac vein was double-sized compared with the right due to portosystemic shunting or marked reduction in the calibre of the right portal vein branches. The predominant splanchnic drainage was via a large paraumbilical varix which drained into the left iliofemoral system (figures 1 and 2).

He was not on warfarin at the time of biopsy and no fresh frozen plasma or platelets (PLT) transfusion was required prebiopsy as International normalised ratio (INR) 1.31 and PLT $11310 \times \times^{9} /$ L. His blood tests on admissions were Haemoglobin $72 \mathrm{~g} / \mathrm{L}$, White cell count $9.88 \times 10^{9} / \mathrm{L}$, PLT $201 \times 10^{9} / \mathrm{L}$, INR 1.3, Albumin $20 \mathrm{~g} / \mathrm{L}$, Sodium $140 \mathrm{mmol} / \mathrm{L}$, Urea $14 \mathrm{mmol} / \mathrm{L}$, Creatinine $210 \mu \mathrm{mol} / \mathrm{L}$, Bilirubin $8 \mu \mathrm{mol} / \mathrm{L}$, Alkaline phosphatase (ALP) $122 \mathrm{IU} / \mathrm{L}$, Aspartate aminotransferase (AST) 27 IU/L, Gammaglutamyl transferase (gGT) 272 IU/L, C-reactive protein (CRP) $3.7 \mathrm{mg} / \mathrm{L}$. He was transfused, given broad-spectrum antibiotics and antifungals and required renal replacement therapy.

During the course of his admission, he developed Fournier's gangrene and an urgent surgical referral was made. The evidence of severe PHT led to a careful assessment and discussion with the surgical team taking into account the anatomy and potential complications during and after intervention. Based on that, a scrotal debridement was successfully performed in two stages with mini-debridement, followed by relook and repair of hydrocele. $\mathrm{He}$ had 47 days ICU stay in view of recurrent sepsis, respiratory wean and need for rehabilitation. The patient recovered and he was admitted to a renal

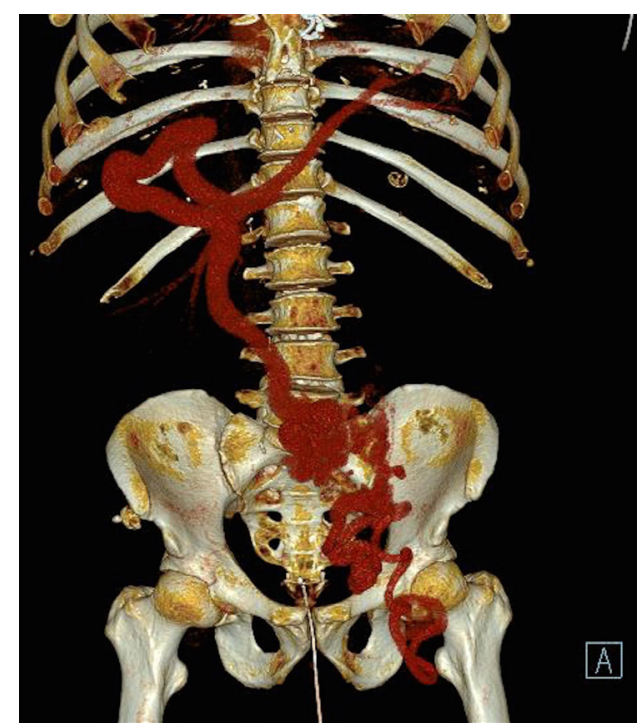

Figure 1 Normal bone, 3D reconstruction of a postcontrast CT scan abdomen/pelvis which demonstrates a left portal vein recanalising to the paraumbilical vein, double-sized left external iliac vein and large paraumbilical varix draining into the left iliofemoral system. 3D, three dimensions.

ward (26 days) for intermittent haemodialysis prior to discharge home. His model for end-stage liver disease (MELD) score before admission to the ICU was 15 and after ward discharge was 27 which demonstrates the degree of decompensation

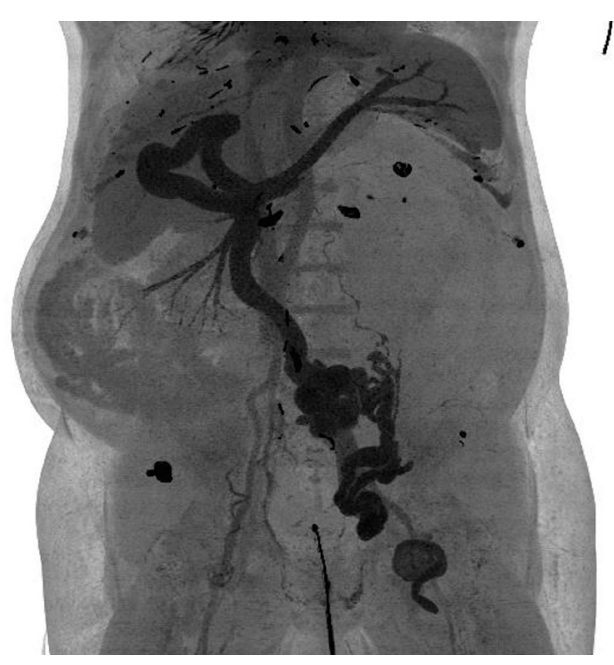

Figure 2 Coronal maximum intensity projection reconstruction of the same postcontrast CT abdomen/ pelvis and description as figure 1 . 
sustained postlarge retroperitoneal bleed, sepsis, invasive interventions and prolonged hospital admission.

This case highlights the importance of reviewing all of the available axial imaging prior to consideration of any surgical intervention. These types of shunts can be a source of hepatic encephalopathy and bleeding. ${ }^{12}$ The potential for massive haemorrhage with any surgical intervention should be considered in cirrhotic patients with PHT and portosystemic shunt. Hepatic venous pressure gradient values $>16 \mathrm{~mm} \mathrm{Hg}$, especially $\geq 20 \mathrm{~mm} \mathrm{Hg}$, have been associated with a high risk of postsurgical mortality. ${ }^{3}$ MELD can be useful to determine operative mortality risk, in fact a score $>20$ has been related to more than 50\% 30-day mortality and a score <or equal to 15 to $25.4 \% .^{4}$

Early referral to a specialist centre is warranted for the interpretation of shunt anatomy and for specialist surgical and interventional radiological input where appropriate. ${ }^{56}$

\section{Learning points}

Importance of reviewing axial imaging prior to consideration of any surgical intervention.

- In patients with cirrhosis with portal hypertension and portosystemic shunt consider potential for massive haemorrhage with any surgical intervention.
Contributors $\mathrm{AC}$ has written the manuscript and facilitated the submission. CW has supervised this work, reviewed and modified the manuscript. SG has supervised this work, selected and edited the images.

Funding The authors have not declared a specific grant for this research from any funding agency in the public, commercial or not-for-profit sectors.

Competing interests None declared.

Patient consent for publication Consent obtained directly from patient(s)

Provenance and peer review Not commissioned; externally peer reviewed.

\section{ORCID iD}

Anna Cavazza http://orcid.org/0000-0003-3720-0463

\section{REFERENCES}

1 Bandali MF, Mirakhur A, Lee EW, et al. Portal hypertension: imaging of portosystemic collateral pathways and associated image-guided therapy. World J Gastroenterol 2017;23:1735-46.

2 Bosch J, Groszmann RJ, Shah VH. Evolution in the understanding of the pathophysiological basis of portal hypertension: how changes in paradigm are leading to successful new treatments. J Hepatol 2015;62:S121-30.

3 Reverter E, Cirera I, Albillos A, et al. The prognostic role of hepatic venous pressure gradient in cirrhotic patients undergoing elective extrahepatic surgery. J Hepatol 2019;71:942-50.

4 Teh SH, Nagorney DM, Stevens SR, et al. Risk factors for mortality after surgery in patients with cirrhosis. Gastroenterology 2007:132:1261-9.

5 Nardelli S, Gioia S, Ridola L, et al. Radiological intervention for shunt related encephalopathy. J Clin Exp Hepatol 2018:8:452-9.

6 Tripathi D, Stanley AJ, Hayes PC, et al. Transjugular intrahepatic portosystemic stentshunt in the management of portal hypertension. Gut 2020:69:1173-92.

Copyright 2021 BMJ Publishing Group. All rights reserved. For permission to reuse any of this content visit

https://www.bmj.com/company/products-services/rights-and-licensing/permissions/

BMJ Case Report Fellows may re-use this article for personal use and teaching without any further permission.

Become a Fellow of BMJ Case Reports today and you can:

- Submit as many cases as you like

- Enjoy fast sympathetic peer review and rapid publication of accepted articles

- Access all the published articles

- Re-use any of the published material for personal use and teaching without further permission

Customer Service

If you have any further queries about your subscription, please contact our customer services team on +44 (0) 2071111105 or via email at support@bmj.com.

Visit casereports.bmj.com for more articles like this and to become a Fellow 